\title{
A Study of Emotional Intelligence and Attitudes Towards Teaching Profession Among Turkish EFL Pre-service Teachers
}

\author{
Huseyin $\mathrm{Oz}^{1} \&$ Hazal Cepik Kiris ${ }^{2}$ \\ ${ }^{1}$ Hacettepe University, Turkey \\ ${ }^{2}$ TUBITAK, Space Technologies Research Institute, Turkey \\ Correspondence: Huseyin Oz, Hacettepe University, Turkey. E-mail: hoz@hacettepe.edu.tr
}

Received: June 8, 2018 Accepted: July 5, 2018 Online Published: July 28, 2018

doi:10.5539/ijel.v8n6p1 URL: https://doi.org/10.5539/ijel.v8n6p1

\begin{abstract}
This study sought to investigate the relationship between emotional intelligence and attitudes towards teaching profession among 124 English as a foreign language (EFL) pre-service teachers at a major state university in Turkey. Data were collected using the Emotional Intelligence Scale and the Attitudes towards Teaching Profession Scale. The collected data were analyzed through descriptive and inferential statistics. Findings indicated that there was a significant positive relationship between emotional intelligence and attitudes towards the teaching profession of Turkish EFL pre-service teachers. Moreover, findings indicated that the majority of the participants had moderate levels of emotional intelligence and attitudes towards teaching profession. Findings may serve as insights for teacher training programs to promote pre-service teachers' emotional intelligence and their attitudes towards the teaching profession.
\end{abstract}

Keywords: emotional intelligence, attitudes, teaching profession, teacher education, preservice EFL teachers

\section{Introduction}

Emotions and attitudes play a crucial role in all human behaviors. Over the past few decades, emotional aspects and attitudes of people have recently attracted a great deal of attention in academic research (Öz, Demirezen, \& Pourfeiz, 2015; Durmusoglu, Yanik, \& Akkoyunlu, 2009). Much research has indicated that emotional intelligence and attitudes are closely linked to foreign language learning (Fahim \& Pishghadam, 2007; López, 2011). There are lots of different interpretations of emotional intelligence and attitude in literature. Emotional intelligence, mostly associated with Goleman (1998), is referred to as "the capacity for recognizing our own feelings and those of others, for motivating ourselves, and for managing emotions well in ourselves and in our relationships" (p. 317). In addition, attitude is defined as people's psychological tendencies that affect their responses to a particular entity in a positive or negative way (Eagly \& Chaiken, 2007). The concepts of emotional intelligence and attitude are also key components of teaching process as they affect teacher competencies. Emotional intelligence influences the behaviors of teachers and the way they think and solve problems (Isen, 1993). Similarly, attitude of teachers towards the teaching profession plays an important role for success in teaching (Terzi \& Tezci, 2007). In this respect, it is fair to say that teaching is not only composed of cognitive competencies but also shaped by affective competencies (Derman, Ozkan, Altuk, \& Mulazimoglu, 2008). Teachers play a paramount role in teaching and learning process of an education system. As emotional intelligence can influence teachers' beliefs on teaching (Anderson, 2004) and their attitude towards the teaching profession can explain their occupational behaviors (Ustuner, 2006), it is important to describe attitudes towards teaching and emotional intelligence of teachers in terms of quality of education. In this point, it is also vital to know pre-service teachers' emotions and points of view about their future profession as they will complete a teacher-training program and become qualified professionals in their field; so exploring this matter will have positive effect on this process. Currently, studies on pre-service teachers' emotional intelligence and attitudes towards the teaching profession are scarce in the field. Therefore, this study attempts to investigate pre-service EFL teachers' emotional intelligence and attitudes towards the teaching profession.

\section{Literature Review}

\subsection{Emotional Intelligence}

The concept of emotional intelligence is often defined as the capability of a person's recognizing his own and 
other people's feelings and emotions (Mayer, DiPaolo, \& Salovey, 1990; Bown \& White, 2010). According to Bar-On (1997), it is "a cross-section of interrelated emotional and social competencies, skills and facilitators that determine how effectively we understand and express ourselves, understand others and relate with them, and cope with daily demands" (p. 3). According to Öz (2015), there are lots of different perspectives on the description of emotional intelligence but it can be clearly interpreted as a person's intrapersonal and interpersonal self-relations. Different studies show that emotional intelligence has an important impact on lots of different areas of one's life including achievement of language. In their study, Alavinia, Bonyadi, and Razavi (2012), for instance, explored that there was a significant correlation between emotional intelligence and L2 learning. Similarly, Pishghadam (2009) revealed that emotional factors greatly affected language learning. In this sense, it is clear that achievement in foreign language learning is emotionally driven as most of researchers have asserted (Dörnyei, 2005; López, 2011). It is also important to discuss the importance of this concept in the field of education as teaching and learning process and the term of being teacher are closely related with emotional features as well as cognitive skills as stated above. Teachers experience lots of different positive and negative emotions such as pleasure, satisfaction, affection, anxiety or frustration (Erb, 2002; Godar, 1990; Hargreaves, 2000; Sutton \& Wheatley, 2003). Therefore, it is said that all teaching is inseparably emotional (Hargreaves, 2001). Notwithstanding the importance of emotional intelligence on teaching process, there are only limited studies exploring the role of this concept on development of pre-service teachers. For instance, Gurol, Ozercan, and Yalcin (2010) investigated the relationship between pre-service teachers' emotional intelligence and their sense of efficacy beliefs and found that there was a significant positive relationship between EI and self-efficacy. Oner and Ulusoy's (2014) study aimed to explore the relationship between pre-service teachers' self-esteem and emotional intelligence and their findings showed that pre-service teachers with high level of self-esteem had high level of emotional intelligence. In another study, Heera and Kaur (2017) sought to determine difference in the emotional intelligence of male and female pre-service teachers. Their findings revealed that male pre-service teachers were more matured and emotionally stable than female counterparts. To sum up, as Koçoğlu (2011) states, emotions of teachers influence their teaching and the way they think on teaching.

\subsection{Attitude}

The concept of attitude is defined as "a mental and neural state of readiness, organized through experience, exerting directive or dynamic influence upon the individual's response to all objects and situations with which it is related" (Allport, 1935, p. 810). Similarly, Kagitcibasi (1999) defined it as a person's positive or negative proneness that has impact on his feelings, beliefs and behaviors toward events, objects and humans. From these definitions, it can be clearly concluded that teachers' attitudes toward the teaching profession would give important clues about most of their occupational behaviours (Ustuner, 2006). There is a large volume of published studies focusing on the association between attitude and the teaching profession (Akbaba, 2013; Bhargava \& Pathy, 2014) and a considerable amount of literature has found that teachers' attitudes towards their profession influence their teaching practice (Al Harthy, Jamaluddin, \& Abedalaziz, 2013). In their study, Ghosh and Bairagya (2010), for instance, revealed that female secondary teachers possess more favorable attitudes towards the teaching profession than male teachers. Similarly, significant difference between male and female teacher trainees' attitude towards the teaching profession was found in a comparative study of Rawat and Sreevastava (1984). Another study (Oruc, 2011) that sought to investigate perceptions of Turkish trainee teachers' attitudes towards teacher profession showed that they have clear positive attitudes toward this profession. According to Duatepe and Akkuş-Çıkla (2004), teaching practices are probably affected negatively by teachers' negative attitudes towards the teaching profession. It is clearly concluded that positive attitudes about the teaching profession promote effective teaching. Similar to this conclusion, Terzi and Tezci (2010) assert that it is not likely to perform a profession productively unless a person has a positive attitude toward it. Therefore, it will be important for teacher candidates to hold positive attitudes toward the teaching profession, as being a teacher requires more than possessing pedagogical knowledge. With this in mind, this study aims to investigate pre-service EFL teachers' emotional intelligence and attitudes towards the teaching profession. Given the scarce literature on emotional intelligence and attitudes towards the teaching profession of pre-service teachers in L2 context, findings of the current study could shed light on this research gap. To this end, the following research questions were formulated to guide the present study:

1) What are the pre-service EFL teachers' emotional intelligence profiles?

2) What are the pre-service EFL teachers' attitudes toward the teaching profession?

3) Is there any relationship between emotional intelligence profile and attitudes toward the teaching profession? 
4) Is there any significant difference between pre-service EFL teachers' emotional intelligence and attitudes toward the teaching profession in relation to gender and age?

5) To what extent can the variation in GPA be predicted by emotional intelligence and attitudes toward the teaching profession?

\section{Method}

\subsection{Research Design}

We employed a quantitative research design and survey methodology to collect data. Participants provided perceptions of their emotional intelligence, attitudes towards the teaching profession and socio-demographic characteristics. Creswell (2012) states that as a cross-sectional study conducted at one point in time, this research design is useful for implementation when researchers try to collect data both quickly and economically.

\subsection{Participants}

The current study was conducted in a pre-service English as a foreign language (EFL) teacher education program at a major state university in Ankara, Turkey in the spring semester of 2017-2018 academic year. A total of 124 pre-service EFL teachers (female: $86,69.35 \%$; male: $38,30.65 \%$ ) in the program voluntarily participated in this study and gave consent for data collection. They ranged in age from 19 to 24 years $(M=20.98, S D=1.30)$.

\subsection{Instruments}

Two different scales were used to gather data in this study. These scales are briefly described below.

\subsubsection{Emotional Intelligence Scale}

Schutte et al.'s (2009) Emotional Intelligence Scale (SEIS) was used to measure the participants' emotional intelligence levels. It includes 33 items and four dimensions (1. perception of emotions (PE), 2. managing one's own emotions (ME), 3. managing others' emotions (MOE), and 4. utilizing emotions (UE). It is a 5-point Likert scale ranging from 1. Strongly disagree to 5. Strongly agree. The internal consistency of the scale was $.78, .84, .63$, and .67 for PE, ME, MOE, and UE subcomponents of emotional intelligence, respectively. As for the overall scale, the internal consistency coefficient was $\alpha=.90$ in this study.

\subsubsection{Attitudes towards Teaching Profession Scale}

Attitudes towards Teaching Profession Scale developed by Ustuner (2006) were used to assess the participants' overall attitudes towards the teaching profession. It is a one-dimensional and 5-point Likert scale with 34 items. The items are rated from 1. Strongly disagree to 5. Strongly agree. The validity and reliability of the scale was conducted by Ustuner (2006) and the result of internal consistency coefficient for the entire scale was $\alpha=.93$. The internal consistency coefficient of the scale was $\alpha=.96$ in present study.

\subsection{Procedures}

Data analysis was carried out to address the research questions formulated for the current study. The statistical analyses were conducted by using IBM SPSS 21 statistical computer program to practice statistical analysis in an accurate and easy way. Descriptive statistics (frequencies and percentages, and means) were performed in order to learn and characterize the participants' levels of emotional intelligence and attitudes towards the teaching profession. To measure the emotional intelligence and attitudes to the teaching profession levels of the participants, their mean scores were classified based on the overall average of the mean score in the given variable. That is, the mean scores falling one standard deviation above the overall average mean score of the variable is considered as high, whereas the ones falling one standard average below the overall average mean score was considered as low. Finally, the mean scores between the two extremes of high and low scores were treated as moderate or medium mean score.

Inferential statistics such as independent-samples $t$ test, one-way analysis of variance (ANOVA) and structural equation modelling (SEM) were also conducted to examine the difference between the participants' emotional intelligence and their attitudes toward the teaching profession in relation to demographic variables such as gender and age groups. Besides, structural equation modelling (SEM) was also conducted to examine the degree to which the participants' emotional intelligence and their attitudes toward the teaching profession can influence their overall grade point averages (GPA).

\section{Findings}

The results of descriptive statistics revealed that, all in all, nearly six out of ten (58\%) of the participants had moderate level of emotional intelligence and $50 \%$ of the participants had moderate level of attitudes toward the teaching profession. As shown in Table 1, 23\% of the participants had high levels in PE, $21 \%$ in ME, $23 \%$ in 
MOE, and $26 \%$ in UE dimensions of emotional intelligence. On the other hand, nearly 2 out of ten (20\%) of the participants reported low levels of emotional intelligence and attitudes toward the teaching profession. The participants reported $18 \%$ of low level in PE, $19 \%$ in ME, $21 \%$ in MOE, and $19 \%$ in UE dimensions of emotional intelligence. As for attitudes toward the teaching profession, $24 \%$ of the participants had high level, $50 \%$ had moderate level, and $26 \%$ had low level of attitudes toward the teaching profession.

Table 1. Emotional intelligence and attitudes toward the teaching profession levels

\begin{tabular}{llll}
\hline & & Rank & Low \\
\cline { 2 - 4 } Variables & High & Mid & $18 \%$ \\
PE & $23 \%$ & $59 \%$ & $19 \%$ \\
ME & $21 \%$ & $60 \%$ & $21 \%$ \\
MOE & $23 \%$ & $56 \%$ & $19 \%$ \\
UE & $26 \%$ & $55 \%$ & $26 \%$ \\
ATTP & $24 \%$ & $50 \%$ & \\
\hline
\end{tabular}

Structural equation modeling (SEM) was conducted to find out if there was a relationship between the indicator variables, i.e. emotional intelligence and attitudes toward the teaching profession, and the participants' cumulative grade point averages (GPA), i.e. their overall academic achievement. As illustrated in Figure 1, emotional intelligence significantly predicted the rate of academic achievement among Turkish pre-service teachers of English. Perception of emotions $(\beta=-.26, p<.01)$, managing of emotions $(\beta=.28, p<.001)$, and utilizing emotions $(\beta=-.34, p<.001)$ were significant predictors of the participants' GPA. However, managing other's emotions did not appear as the predictor of GPA. The findings also indicated significant strong correlation paths among all predictor variables $(p<.001)$ except for MOE and UE dimensions, which were found to be moderately correlated with each other. An inspection of squared multiple correlations further revealed that emotional intelligence explained $10 \%$ of the variance in the participants' academic achievement.

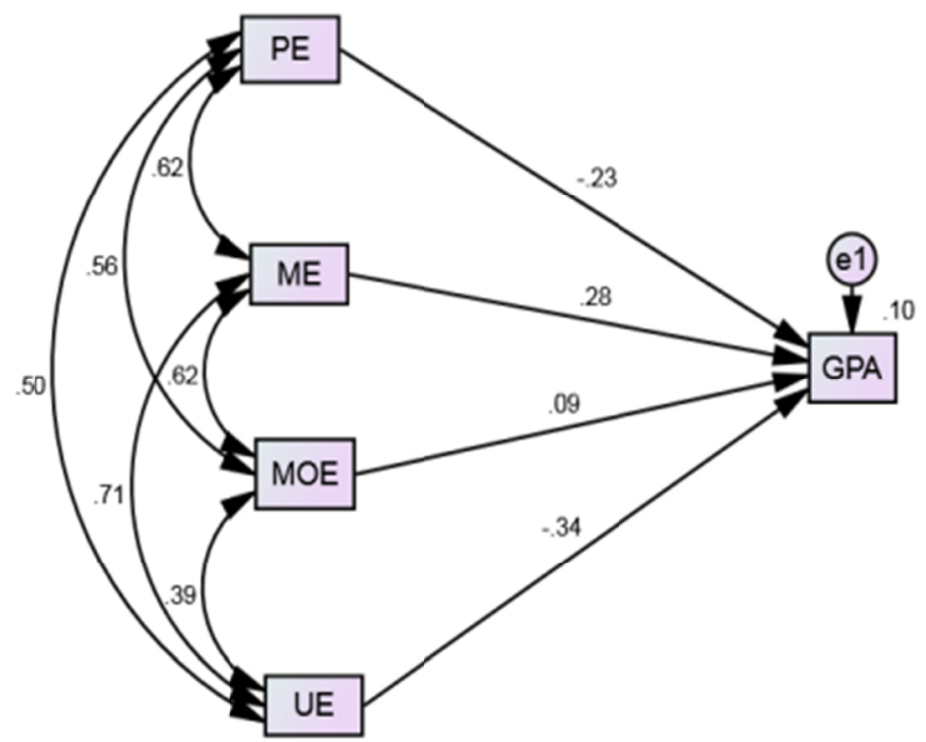

Figure 1. The relationship between emotional intelligence and GPA

Likewise, as shown in Figure 2, attitudes toward the teaching profession significantly predicted the rate of academic achievement among Turkish pre-service teachers of English $(\boldsymbol{\beta}=.33, \mathbf{p}<.001)$, accounting for $11 \%$ of the variance in the participants' GPA.

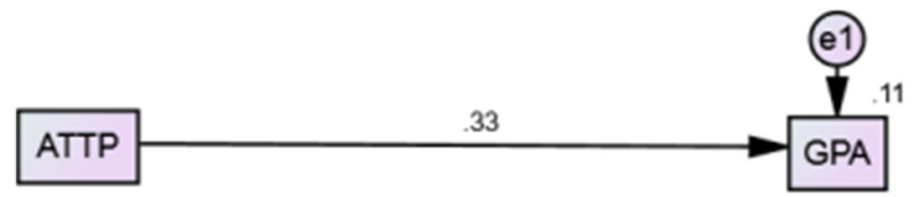

Figure 2. The relationship between attitudes toward the teaching profession and GPA 
Further analysis was run to measure the joint effect of both emotional intelligence and attitudes toward the teaching profession on overall GPA. The findings were found to be promising and, taken together, emotional intelligence and attitudes toward the teaching profession significantly predicted the rate of academic achievement among the participants. Perception of emotion $(\beta=-.28, p<.01)$ and utilizing emotions $(\beta=-.29, p$ $<.001$ ) were significant predictors of the participants' GPA. However, managing of emotions and managing others' emotions had no impact on overall GPA. Furthermore, as shown in Figure 3, attitudes toward the teaching profession greatly influenced GPA and, indeed, it appeared as the strongest predictor of it $(\beta=.53, p<.001)$. Together, emotional intelligence and attitudes toward the teaching profession accounted for $28 \%$ of the variance in the participants' overall GPA.

An examination of covariance values, as illustrated in Figure 3, revealed all the subcomponents of emotional intelligence significantly correlated with attitudes toward the teaching profession. A strong significant correlation was observed between managing emotions and attitudes toward the teaching profession $(p>.56)$. However, managing others' emotions, perceptions, and utilizing emotions moderately correlated with attitudes toward the teaching profession, respectively. The p-value appeared to be larger than the threshold level $(p>.29)$. According to Cohen (1988), correlation coefficients indexes for strong, medium, and small significance are $\pm 0.50, \pm 0.30$, and \pm .29 , respectively.

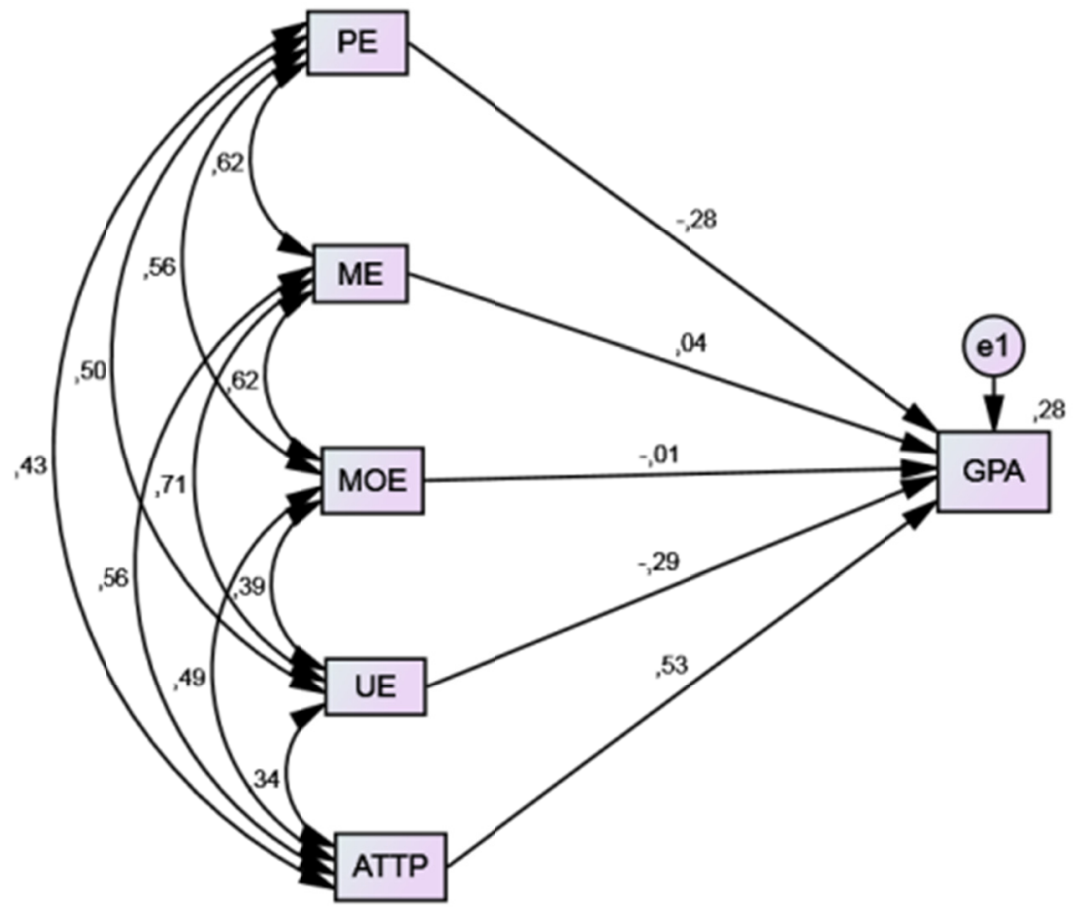

Figure 3. The relationship between emotional intelligence, attitudes toward the teaching profession, and GPA

An in independent samples t-test was conducted to find out if there is any significant difference between pre-service EFL teachers' emotional intelligence and attitudes toward the teaching profession in relation to gender. The findings revealed no statistically significant difference, $t(122), p>.05)$, between male and female participants in terms of their perception of intelligence and attitudes toward the teaching profession.

To find out whether the participants' perceptions of emotional intelligence and attitudes toward the teaching profession differ in relation to age factor, a one-way analysis of variance (ANOVA) was run. The findings, as shown in Table 2, indicated statistically significant difference among the participants in perception of emotions dimension of emotional intelligence, $F(5,118)=2.71, p<.05)$, and attitudes toward the teaching profession, $F$ $(5,118)=4.77, p<.05)$. Furthermore, the results of Tukey's post-hoc analysis demonstrated that the exact difference was observed between age groups of 19 and 21, with age group of 19 having less mean score, $(M$ $=35.80, S D=4.82)$, than the age group of $21,(M=40.34, S D=5.47)$, and other groups, indicating that the less the age of the participants, the lower the level of perception of emotions will be. Likewise, significant difference was seen between the age group of 19 and the age groups of 21 and 22, again, with age group of 19 having less mean score, $(M=110.700, S D=24$. 11$)$, than the other groups. 
Table 2. The relationship between age factor, emotional intelligence and attitudes toward the teaching profession

\begin{tabular}{|c|c|c|c|c|c|c|c|}
\hline & & $\mathrm{N}$ & Mean & SD & $\mathrm{F}$ & Df & Sig. \\
\hline \multirow{7}{*}{ PE } & 19.00 & 20 & 35.80 & 4.82 & \multirow{7}{*}{2.71} & & \multirow{7}{*}{.024} \\
\hline & 20.00 & 20 & 37.70 & 7.80 & & & \\
\hline & 21.00 & 46 & 40.34 & 5.47 & & & \\
\hline & 22.00 & 24 & 38.66 & 4.05 & & 5 & \\
\hline & 23.00 & 8 & 38.50 & 2.32 & & 118 & \\
\hline & 24.00 & 6 & 42.66 & 5.68 & & & \\
\hline & Total & 124 & 38.85 & 5.65 & & & \\
\hline \multirow{7}{*}{$\mathrm{ME}$} & 19.00 & 20 & 34.80 & 6.45 & \multirow{7}{*}{1.18} & & \multirow{7}{*}{.319} \\
\hline & 20.00 & 20 & 35.30 & 5.23 & & & \\
\hline & 21.00 & 46 & 37.13 & 6.47 & & & \\
\hline & 22.00 & 24 & 35.50 & 4.09 & & 5 & \\
\hline & 23.00 & 8 & 34.75 & 5.14 & & 118 & \\
\hline & 24.00 & 6 & 39.66 & 4.50 & & & \\
\hline & Total & 124 & 36.11 & 5.74 & & & \\
\hline \multirow{7}{*}{ MOE } & 19.00 & 20 & 30.90 & 3.65 & \multirow{7}{*}{1.89} & & \multirow{7}{*}{.101} \\
\hline & 20.00 & 20 & 30.40 & 5.47 & & & \\
\hline & 21.00 & 46 & 32.34 & 3.62 & & & \\
\hline & 22.00 & 24 & 31.00 & 3.36 & & 5 & \\
\hline & 23.00 & 8 & 32.25 & 4.36 & & 118 & \\
\hline & 24.00 & 6 & 35.00 & .89 & & & \\
\hline & Total & 124 & 31.66 & 3.98 & & & \\
\hline \multirow{7}{*}{ UE } & 19.00 & 20 & 24.20 & 4.34 & \multirow{7}{*}{.71} & & \multirow{7}{*}{.617} \\
\hline & 20.00 & 20 & 24.80 & 2.33 & & & \\
\hline & 21.00 & 46 & 25.56 & 3.47 & & & \\
\hline & 22.00 & 24 & 24.75 & 2.57 & & 5 & \\
\hline & 23.00 & 8 & 24.25 & 3.73 & & 118 & \\
\hline & 24.00 & 6 & 26.00 & 4.09 & & & \\
\hline & Total & 124 & 25.00 & 3.34 & & & \\
\hline \multirow{7}{*}{ ATTP } & 19.00 & 20 & 110.70 & 24.11 & \multirow{7}{*}{4.77} & & \multirow{7}{*}{.001} \\
\hline & 20.00 & 20 & 121.70 & 31.89 & & & \\
\hline & 21.00 & 46 & 139.21 & 23.94 & & & \\
\hline & 22.00 & 24 & 138.50 & 21.33 & & 5 & \\
\hline & 23.00 & 8 & 126.50 & 28.73 & & 118 & \\
\hline & 24.00 & 6 & 138.00 & 14.93 & & & \\
\hline & Total & 124 & 130.77 & 26.81 & & & \\
\hline
\end{tabular}

\section{Discussion}

This study set out with the aim of investigating pre-service English a foreign language (EFL) teachers' emotional intelligence and attitudes towards the teaching profession. With regard to the first research question-emotional intelligence profiles of participants - the results demonstrated that pre-service EFL teachers had moderate levels of emotional intelligence. This finding is consistent with that of Koçoğlu (2011) who found that Turkish EFL pre-service teachers' emotional intelligence competencies were in the average range. As previous studies emphasize, emotional intelligence influences teaching competencies (Bandura, 1997), and EI competencies promote effective teaching (Cohen, 2001). Therefore, teacher education programs could develop a sense of emotional intelligence among pre-service teachers during their teacher training. In line with this conclusion, Tschannen-Moran and Woolfolk- Hoy (2001) also argue that it is important for teacher education programs to develop emotional intelligence of pre-service teachers.

With regard to the participants' attitudes towards the teaching profession, findings of this research question revealed that the majority of the participants had moderate levels of attitudes towards the teaching profession. Similar studies have also reported moderate and positive attitudes among pre-service teachers towards the teaching profession (Kocaarslan, 2014; Oral, 2004; Tanel, Şengören, \& Tanel, 2007; Üstün, Erkan, \& Akman, 2004; Yanik, 2017). There is a growing body of literature on attitudes towards the teaching profession, suggesting that having positive attitudes toward teaching is important for teachers to perform effective and successful teaching (Erawan, 2011; Kaya \& Büyükkasap, 2005). Therefore, it can be said that teacher training programs have a central role in developing pre-service teachers' attitudes toward their future profession. 
Another finding of this study was that there was a significant relationship between emotional intelligence and attitudes toward the teaching profession among the participants. This finding shows that as the emotional intelligence level of pre-service teachers increases, the level of their attitude towards the teaching profession increases as well. This finding corroborates that of Kayserili and Gundogdu's (2010) work that also reported a significant relationship between pre-service teachers' attitudes towards the teaching profession and emotional intelligence levels. Similarly, previous studies also emphasize that emotional intelligence leads to more positive attitudes (Akerjordet \& Severinsson, 2007). For this reason, it can be suggested that teacher training programs should also aim to promote pre-service teachers' emotional competences and positive attitudes towards the teaching profession.

The findings of the present study also demonstrated that there was no significant difference in emotional intelligence and attitudes toward the teaching profession between male and female pre-service teachers. This finding is consistent with that of Semerci and Semerci (2004) who found that attitudes of pre-service teachers towards the teaching profession did not show significant difference by gender. Gürol, Ozercan, and Yalcin (2013) and Herguner (2017) also reported that emotional intelligence levels of male and female participants showed no statistically significant difference. On the other hand, some of the studies concluded that there were significant differences in male and female pre-service teachers' attitudes towards the teaching profession and emotional intelligence (Benjamin, Sahayarani, \& Stanly, 2011; Çarpi \& Çelikkaleli, 2008; Ustuner, Demirtaş, \& Cömert, 2009; Reisoglu, Gedik, \& Goktas, 2013).

Another finding of the current study indicated that there was a significant difference between participants' age groups in terms of their perception of emotional intelligence and attitudes toward the teaching profession. In other words, it was revealed that the participants with lower age perceived that they had less control over their emotions and lower levels of attitudes toward the teaching profession. Therefore, it could be concluded that the lack of difference among participants with higher age levels is indicative of more control over their emotions and perceive more positive attitudes toward the teaching profession. In line with this conclusion, Cinpolat, Alincak, and Abakay (2016) found that there were differences in attitudes of pre-service teachers towards the teaching profession in terms of age and it was concluded that participants in the higher age group had a better attitude towards the teaching profession. Similarly, this conclusion corroborates with the belief of Baron (2006) who asserts that age brings about more emotional intelligence. In addition, different studies indicate that emotional intelligence increases with age (Mayer, Caruso, \& Salovey, 1999) and age influences the attitudes (Bhargava \& Pathy, 2014). Therefore, this finding of the current study is not surprising. On the other hand, there are also some studies showing that age difference has no influence on student teachers' emotional intelligence (Yusuf, Yusuf, \& Gambari, 2015) and attitudes towards the teaching profession (Ekici, 2014).

Consistent with the literature, the present research found that emotional intelligence and attitudes toward the teaching profession significantly predicted the rate of academic achievement among the participants. In fact, the majority of the studies in the literature show that there is a positive relationship between emotional intelligence and academic achievement (Jaeger, 2003; Kavcar, 2011; Petrides, Fredericson, \& Furnham, 2004) and academic achievement and pre-service teachers attitudes towards the teaching profession (Abbasoglu \& Oncu, 2013). On the other hand, some studies argue that there is no connection between these two variables (Erdogdu \& Kenarli, 2008; Özder, Konedral1, \& Zeki, 2010). These different findings may be due to the differences in the sample groups. Given the critical importance of emotional intelligence and attitudes towards the teaching profession among pre-service teachers, it can be clearly concluded that these two concepts will obviously influence the academic achievement of student-teachers.

\section{Conclusions}

The main goal of the current study was to investigate the possible association between pre-service EFL teachers' emotional intelligence (EI) and their attitudes towards the teaching profession. The findings of this study revealed that there was a significant positive correlation between the two variables. The current study shed light on the relationship between EI and attitudes towards the teaching profession. This relationship is an important point in L2 context. However, it is an under-researched issue and has not been explored adequately in L2 research. Therefore, the further research should pay more attention to this issue. Otherwise, we may fail to understand educational outcomes of the relationship between EI and attitudes towards the teaching profession.

Moreover, as developing the high level of emotional intelligence and positive attitudes towards the teaching profession can help pre-service teachers to be more effective in their teaching process, much emphasis on this issue should be put in the curriculum. In the light of the findings of this study, it seems reasonable that teacher training programs should promote pre-service teachers' emotional intelligence and their attitudes towards the 
teaching profession. This study has showed the importance of emotional intelligence and attitudes of pre-service teachers. Therefore, another possible study could investigate how pre-service teachers can foster positive attitudes towards the teaching profession and strategies to develop high level of emotional intelligence. On the other hand, as the investigations into emotional intelligence and attitude towards the teaching profession are a new area of inquiry in L2 studies and the sample size of this research is limited, generalizations about the findings of this study must be made cautiously.

\section{References}

Abbasoglu, E., \& Oncu, E. (2013). Pre-service physical education teachers' self-esteems and attitudes toward teaching profession. Ahi Evran Üniversitesi Kırşehir Eğitim Fakültesi Dergisi (KEFAD), 14(2), 407-425.

Akbaba, B. (2013). The attitudes of pre-service social studies teachers' towards teaching profession and their self-efficacy about using instruction materials. Mevlana International Journal of Education, 3(2), 157-169. https://doi.org/10.13054/mije.13.46.3.2

AkerJordet, K., \& Severinsson, E. (2007). Emotional intelligence: A review of the literature with specific focus on empirical and epistemological perspectives. Journal of Clinical Nursing, 16(8), 1405-1416. https://doi.org/10.1111/j.1365-2702.2006.01749.x

Al Harthy, S. S. H., Jamaluddin, S., \& Abedalaziz, N. D. (2013). Teachers' attitudes and performance: An analysis of effects due to teaching experience. International Interdisciplinary Journal of Education, 2(9), 888-893. https://doi.org/10.12816/0002957

Alavinia, P., Bonyadi, A., \& Razavi, N. (2012). On the correlation between teachers' emotional intelligence and learners' motivation: The case of Iranian EFL learners. Journal of Education and Practice, 3(13), 100-110.

Allport, G. W. (1935). Attitudes. In C. M. Murchison (Ed.), Handbook of social psychology (pp. 798-844). Winchester, MA: Clark University Press.

Anderson, L. (2004). Increasing teacher effectiveness. Paris: UNESCO, International Institute for Educational Planning.

Bandura, A. (1997). Self-efficacy: Toward a unifying theory of behavioral change. Psychological Review, 84(2), 191-215. https://doi.org/10.1037/0033-295X.84.2.191

Bar-On, R. (1997). Bar-on emotional quotient inventory (eq-i): Technical manual. Toronto: Multi-Health Systems.

Bar-On, R. (2006). The bar-on model of emotional-social intelligence (ESI). Psicothema, 18, 13-25.

Benjamin, A. E. W., Sahayarani, J., \& Stanly, L. S. (2011). A study on attitude towards teaching profession and achievement in teaching competency of b.Ed. Trainees. New Frontiers in Education, 44(3), 250-253.

Bhargava, A., \& Pathy, M. K. (2014). Attitude of student teachers towards teaching profession. Turkish Online Journal of Distance Education-TOJDE, 15(3), 27-36. https://doi.org/10.17718/tojde.15072

Bown, J., \& White, C. J. (2010). Affect in a self-regulatory framework for language learning. System, 38(3), 432-443. https://doi.org/10.1016/j.system.2010.03.016

Çapri, B., \& Çelikkaleli, Ö. (2008). Investigation of preservice teachers' attitudes towards teaching and professional self-efficacy beliefs according to their gender, programs, and faculties. Inonu University Journal of the Faculty of Education, 9(15), 33-53.

Cinpolat, T., Alıncak, F., \& Abakay, U. (2016). Investigation of attitudes of the students of physical education and sports towards teaching profession. Journal of Gaziantep University Sports Sciences, 1(1), 38-47.

Cohen, J. (2001). Social emotional education. In J. Cohen (Ed.), Caring classrooms/intelligent schools (pp. 3-29). New York: Teachers College Press.

Creswell, J. W. (2012). Educational research: Planning, conducting, and evaluating quantitative and qualitative research. Boston, MA: Pearson.

Dağlı, E. M. (2006). Ergenlikte zeka bölümü, duygusal zeka ve akademik başarı arasındaki ilişki (Unpublished master thesis). Mersin University, Mersin.

Derman, A., Özkan, E., Altuk, Y., \& Mülazimoğlu, İ. E. (2008). An investigation of chemistry student teachers' attitudes toward teaching profession according to some factors. Ahi Evran Üniversitesi Kırşehir Eğitim Fakültesi Dergisi (KEFAD), 9(2), 113-127. 
Dörnyei, Z. (2005). The psychology of the language learner: Individual differences in second language acquisition. Mahwah, NJ: Erlbaum.

Duatepe, A., \& Akkus-Çıkla, O. (2004). The attitudes towards teaching professions of in-service and preservice primary school teachers. Pedagogika, 70, 61-65.

Durmusoglu, M. C., Yanik, C., \& Akkoyunlu, B. (2009). Turkish and Azerbaijani prospective teachers' attitudes to their profession. Hacettepe University Journal of Education, 36, 76-86.

Eagly, A. H., \& Chaiken, S. (2007). The advantages of an inclusive definition of attitude. Social Cognition, 25(5), 582-602. https://doi.org/10.1521/soco.2007.25.5.582

Ekici, F. Y. (2014). Examining prospective teachers' attitudes towards teaching profession in terms of various variables (Sabahattin Zaim University Sample). The Journal of International Social Research, 7(35), 658-665.

Erawan, P. (2011). A path analysis for factors affecting pre-service teachers' teaching efficacy. American Journal of Scientific Research, 13, 47-58.

Erb, C. S. (2002). The emotional whirlpool of beginning teachers' work. Paper presented at the annual meeting of the Canadian Society of Studies in Education, Toronto, Canada.

Erdoğdu, M. Y., \& Kenarlı, Ö. (2008). Duygusal zeka ile akademik başarı arasındaki ilişki. Milli Ĕgitim, 178, 297-311.

Fahim, M., \& Pishghadam, R. (2007). On the role of emotional, psychometric, and verbal intelligences in the academic achievement of university students majoring in English language. Asian EFL Journal, 9, 240-253.

Ghosh, S., \& Bairgya, S. (2010). Attitude of secondary school teachers towards teaching profession in relation to some demographic variables. Edusearch, 1(1), 55-58.

Godar, J. (1990). Teachers talk. Macombn. IL: Glenbridge Publishing.

Goleman, D. (1998). Working with emotional intelligence. New York: Bantam Books.

Gürol, A., Ozercan, M. G., \& Yalcin, H. (2010). A comparative analysis of pre-service teachers' perceptions of self-efficacy and emotional intelligence. Procedia Social and Behavioral Sciences, 2(2), 3246-3251. https://doi.org/10.1016/j.sbspro.2010.03.496

Hargreaves, A. (2000). Mixed emotions: Teachers' perceptions of their interactions with students. Teaching and Teacher Education, 16(8), 811-826. https://doi.org/10.1016/S0742-051X(00)00028-7

Hargreaves, A. (2001). Emotional geographies of teaching. Teachers College Record, 103(6), 1056-1080. https://doi.org/10.1111/0161-4681.00142

Heera, P., \& Kaur, A. (2017). A study of emotional intelligence of pre-service teachers. International Education and Research Journal, 3(1), 69-70.

Herguner, S. (2017). Prospective EFL teachers' emotional intelligence and tablet computer use and literacy. TOJET: The Turkish Online Journal of Educational Technology, 16(4), 56-64.

Isen, A. M. (1993). Positive affect and decision-making. In M. Lewis \& J. Haviland (Eds.), Handbook of emotions (pp. 261-277). New York, NY: Guilford Press.

Jaeger, A. J. (2003). Job competencies and the curriculum: An inquiry into emotional intelligence in graduate professional education. Research in Higher Education, 44(6), 615-639. https://doi.org/10.1023/A:1026119724265

Kağıtçıbaşı, Ç. (1999). Yeni insan ve insanlar. İstanbul: Evrim Yayinevi.

Kaya, A., \& Büyükkasap, E. (2005). Physics student teachers' profiles, attitudes and anxiety toward teaching profession: An Erzurum sample. Kastamonu Education Journal, 13(2), 367-380.

Kayserili, T., \& Gündoğdu, K. (2010). Okul öncesi öğretmenleri ve öğretmen adaylarının mesleğe ilişkin tutumları ile duygusal zekâları arasındaki ilişki. Milli Eğitim, 187, 104-121.

Kocaarslan, M. (2014). Öğretmen adaylarının öğretmenlik mesleğine ilişkin tutumlarının incelenmesi. Asya Öğretim Dergisi, 2(1), 46-55.

Koçoğlu, Z. (2011). Emotional intelligence and teacher efficacy: A study of Turkish EFL pre-service teachers. Teacher Development: An International Journal of Teachers' Professional Development, 15(4), 471-484. https://doi.org/10.1080/13664530.2011.642647 
López, M. M. (2011). The motivational properties of emotions in foreign language learning. Colombian Applied Linguistics Journal, 13(2), 43-57. https://doi.org/10.14483/22487085.3764

Mayer, J. D., Caruso, D., \& Salovey, P. (1999). Emotional intelligence meets traditional standards for an intelligence. Intelligence, 27, 267-298. https://doi.org/10.1016/S0160-2896(99)00016-1

Mayer, J. D., Dipaolo, M., \& Salovey, P. (1990). Perceiving affective content in ambiguous visual-stimuli-a component of emotional intelligence. Journal of Personality Assessment, 54(3-4), 772-781. https://doi.org/10.1080/00223891.1990.9674037

Önen, A. S., \& Ulusoy, F. M. (2015). The relationship between pre-service teachers' self-esteem and emotional intelligence levels. Procedia - Social and Behavioral Sciences, 186, 1163-1168. https://doi.org/10.1016/j.sbspro.2015.04.195

Oral, B. (2004). The attitudes of students of education faculty towards teaching professions. Ĕgitim Araştırmaları Dergisi, 15, 88-98.

Oruç, N. (2011). The perception of teaching as a profession by Turkish trainee teachers: Attitudes towards being a teacher. International Journal of Humanities and Social Science, 1(4), 83-87.

Öz, H. (2015). Emotional intelligence as a predictor of L2 communication. Procedia - Social and Behavioral Sciences, 186, 424-430. https://doi.org/10.1016/j.sbspro.2015.04.117

Öz, H., Demirezen, M., \& Pourfeiz, J. (2015). Willingness to communicate of EFL learners in Turkish context. Learning and Individual Differences, 37, 269-275. https://doi.org/10.1016/j.lindif.2014.12.009

Özder, H., Konedralı, G., \& Zeki, C. P. (2010). Examining the attitudes towards the teaching profession and academic achievements of prospective teachers. Educational Administration: Theory and Practice, 16(2), 253-275.

Petrides, K. V., Frederickson, N., \& Furnham, A. (2004). The role of trait emotional intelligence in academic performance and deviant behavior at school. Personality and Individual Differences, 36(2), 277-293. https://doi.org/10.1016/S0191-8869(03)00084-9

Pishghadam, R. (2009). A quantitative analysis of the relationship between emotional intelligence and foreign language learning. Electronic Journal of Foreign Language Teaching, 6(1), 31-41.

Rawat, B. M., \& Sreevastava, R. K. (1984). Attitude of male and female teacher trainees towards teaching: A comparative study. Asian journal of Psychology and Education, 13(2-4), 54-58.

Reisoglu, I. G., N., \& Goktas, Y. (2013). Relationship between pre-service teachers' levels of self-esteem, emotional intelligence and problematic internet use. Education and Science, 38(170), 150-163.

Schutte, N. S., Malouff, J. M., \& Bhullar, N. (2009). The assessing emotions scale. In C. Stough, D. H. Saklofske, \& J. D. Parker (Eds.), Assessing emotional intelligence: Theory, research, and applications (pp. 119-134). Springer, Boston: MA. https://doi.org/10.1007/978-0-387-88370-0_7

Semerci, N., \& Semerci, Ç. (2004). Attitudes toward teaching in Turkish. Firat University Journal of Social Science, 14(1), 137-146.

Sutton, R.E., \& Wheatley, K.F. (2003). Teachers' emotions and teaching: A review of the literature and directions for future research. Educational Psychology Review, 15(4), 327-358. https://doi.org/10.1023/A:1026131715856

Tanel, R., Şengören, S. \& Tanel, Z. (2007). Investigating attitudes of prospective physics teachers towards teaching as a profession regarding various variables. Pamukkale University Journal of Education, 2(22), $1-9$.

Terzi, A. R., \& Tezci, E. (2007). The attitudes of the students towards teaching profession at Necatibey Education Faculty. Educational Administration: Theory and Practice, 52, 593-614.

Tezci , E., \& Terzi , A. R. (2010). An examination on the attitudes towards teaching profession of the students of secondary school branch teacher training programs. e-Journal of New World Sciences Academy, 5(2), 367-388.

Tschannen-Moran, M., \& Hoy, A. W. (2001). Teacher efficacy: Capturing an elusive construct. Teaching and Teacher Education, 17(7), 783-805. https://doi.org/10.1016/S0742-051X(01)00036-1

Üstün, E., Erkan, S., \& Akman, B. (2004). Türkiye’de okul öncesi öğretmenliği öğrencilerinin öğretmenliğe ilişkin tutumlarının incelenmesi. Manas Üniversitesi Sosyal Bilimler Dergisi, 10(2), 129-136. 
Üstüner, M. (2006). Reliability and validity study of an attitude scale of teaching profession. Educational Administration: Theory and Practice, 45, 109-127.

Üstüner, M., Demirtaş, H., \& Cömert, M. (2009). The attitudes of prospective teachers towards the profession of teaching (the case of Inonu University, faculty of education). Education and Science, 35(151), 140-155.

Yanik, M. (2017). The beliefs of self-sufficiency of candidate teachers of physical education and sport. Journal of Physical Education and Sport Sciences, 19(4), 148-161.

Yusuf, H. T., Yusuf, A., \& Gambari, A. I. (2015). Emotional intelligence of student - teachers in relation to their future productivity. The African Symposium: An Online Journal of the African Educational Research Network, 15(1), 25-34.

\section{Copyrights}

Copyright for this article is retained by the author(s), with first publication rights granted to the journal.

This is an open-access article distributed under the terms and conditions of the Creative Commons Attribution license (http://creativecommons.org/licenses/by/4.0/). 